\title{
American Pediatric Society Presidential Address 2008: Research in Early Life - Benefit and Promise
}

\author{
WILLIAM W. HAY, JR. \\ University of Colorado School of Medicine, University of Colorado Denver, Aurora, Colorado 80045
}

$\mathrm{M}$ embers of the American Pediatric Society (APS) and guests: It is my pleasure to address this APS Presidential Plenary Session in this 120 th year of our society. I want to thank the members of the APS for granting me the privilege to serve as your president this year, a truly wonderful honor that I will cherish forever.

\section{RESEARCH IN EARLY LIFE-ADAPTATIONS TO ENVIRONMENTAL DISTURBANCES}

My fellowship mentor, Fred Battaglia, spoke eloquently about the remarkable commonality among fetuses of different species-relatively similar diets, metabolic rates, and growth of body structures (1). When I actually looked at the remarkable variety of human newborns, however, I was struck by how different they could be (Fig. 1) (2). Clearly, within a species, fetal growth and development can take on quite different shapes and sizes and functional capacities. More importantly, the extremes of fetal growth increase both immediate and long-term morbidity and mortality $(3,4)$. This observation set up my career long goals; first, to learn how such diversity of fetal development comes about and second, to learn from such diversity how we might return deviant growth and function to more normal patterns.

Fundamental to understanding the variations in growth and development is the observation that much of development consists of adaptations to environmental disturbances, designed through evolution to produce a successful birth of a viable infant. Others have added new observations to this basic concept, showing that although adaptations to various disturbances in early life might have an immediate, positive benefit, such adaptations in turn set up the individual to develop adverse outcomes later in life if presented with a different sort of environment or way of life (3-7). The underlying mechanism for this "developmental origins" phenomenon, as coined by David Barker and others $(8,9)$, has been labeled "programming (10)."

Received June 27, 2008; accepted August 16, 2008

Correspondence: William W. Hay, Jr., M.D., University of Colorado Denver F441, Perinatal Research Center, 13243 East 23rd Avenue, PO Box 6508, Aurora, CO 80045-2526; e-mail: bill.hay@uchsc.edu

Supported by NIH-NCRR U54RR025217-01 Clinical Translational Science Award.

Presented at the 2008 Annual Meeting of the Pediatric Academic Societies, Honolulu, Hawaii.
One of the major nutritional programming studies in our laboratory was to understand fetal metabolic adaptations to decreased glucose supply. We considered this important, because placental insufficiency that causes intrauterine growth restriction (IUGR) does this, in part, by chronically reducing the supply of glucose to the fetus. We were surprised, after first showing that experimental glucose deficiency in a normal fetus slowed its growth rate (11) to observe that fetal glucose utilization rate in the growth restricted fetus is normal for body size, even at the prevailing low glucose and insulin concentrations that are characteristic of the growth restricted fetus $(12,13)$. The apparent cause of this fascinating adaptation is an increase in the capacity for glucose uptake and metabolism, mediated at the cellular level by up-regulation of both glucose- and insulin-responsive glucose transporter expression (14). Thus, at the prevailing low glucose and insulin concentrations in the IUGR fetus, glucose uptake and utilization are maintained at normal body weight-specific rates. Although some have likened this process to a "thrifty phenotype" (15), it represents a common biologic phenomenonincreased capacity for uptake of what is essential, in this case, a substrate for energy production, to ensure survival in response to nutrient deprivation.

In contrast, fetal growth rate is sacrificed when fetal nutrient supply is chronically reduced. The various mechanistic adaptations involve down-regulation of the proteins of the integrated insulin and growth factor signaling and amino acid metabolic pathways, which then limit the synthesis of amino acids into protein as well as rates of cell proliferation and growth $(16,17)$. In this case, the biologic phenomenon is to limit what is expendable and not necessary for survival - growth rate and body size - in response to nutrient deprivation.

In selected cell populations, specifically the insulin producing $\beta$-cells of the pancreas, fetal nutrient deficiency leads to $\beta$-cell cell cycle arrest, production of fewer $\beta$-cells and

Abbreviations: APS, American Pediatric Society; BRDPI, Biomedical Research and Development Price Index; IUGR, Intrauterine Growth Restriction; NICHD, National Institute of Child Health and Human Development; NIH, National Institutes of Health; NCRR, National Center for Research Resources; NICU, Neonatal Intensive Care Unit; PAS, Pediatric Academic Societies; PPC, Public Policy Council 
4 - fold weight variance among term human newborns.

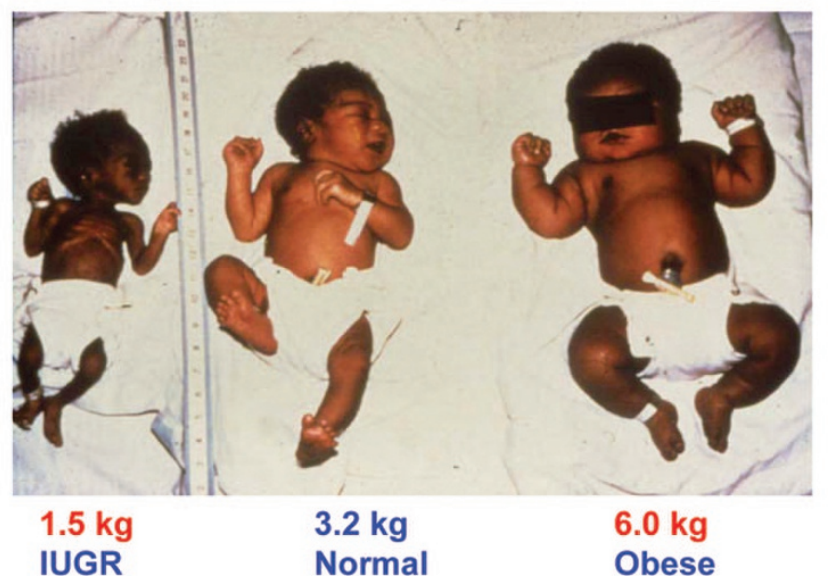

Figure 1. Both extremes of fetal growth, intrauterine growth restriction (IUGR, left panel) and macrosomia (as in the obese infant of a gestational diabetic mother, right panel), lead to similar adult pathologic conditions of obesity, insulin resistance, diabetes, and cardiovascular disease, representing the serious impact on health and disease in later life that stems from adaptations to disturbances in growth and development in early life.

smaller islets, and reduced capacity of the fetal pancreas to secrete insulin $(18,19)$. The biologic phenomenon in this case is to limit production of insulin to prevent a mismatch between its anabolic effects and diminished nutrient supply.

Emerging from these studies is the unique IUGR phenotype, in which reduced nutrient supply to the fetus results in up-regulation of glucose utilization capacity, down-regulation of mechanisms underlying cell growth, and reduced capacity to produce a now unnecessary anabolic hormone, insulin. These are appropriate adaptations to adjust fetal metabolism and growth to nutrient supply, ensuring immediate survival to allow fetal development and growth to continue and produce a viable offspring at birth. It is reasonable to predict from these adaptations - increased avidity of the IUGR offspring to take up glucose but reduced capacity to grow more muscle and bone- that if the mechanisms responsible for these metabolic adaptations were "programmed" into the IUGR offspring, later life conditions of excess sugar intake and limited energy expenditure might lead to excessive calorie deposition in fat stores, thereby producing obesity, insulin resistance, and diabetes, as well as short stature and diminished muscle development.

The same adverse consequences of inadequate fetal nutrition also occur in preterm infants, those that are still in the sensitive fetal developmental stages of life, but now living outside the uterus in the neonatal intensive care unit (NICU). The growth of these infants is poor and nearly all are significantly growth-restricted by term gestational age, as studies from the National Institute of Child Health and Human Development (NICHD) Neonatal Research Network clearly document (20). If these preterm infants were still fetuses, they would receive more protein than we generally feed them, up to $4 \mathrm{~g} / \mathrm{kg} / \mathrm{d}$ at $24-28$ wk gestation $(21,22)$, and when we do feed them this much protein, their protein balance responds positively, a universally consistent research and clinical observation $(23,24)$. If not fed this amount of nutrition, particularly of protein, the consequences for such infants are clear-later life short stature, reduced muscle mass, and smaller brains that do not allow normal cognitive development. The good news, however, is that there is potential for improved brain growth and intellectual development if preterm infants are fed diets that supply nutrients at the appropriate rates necessary for normal fetal growth. Preterm infants fed preterm formula (with more protein and nonprotein energy) have measurably improved developmental and intellectual outcomes in early childhood (25). By adolescence, brain structural development and verbal IQ are directly related to the original amount of nutrient intake, particularly of protein $(26,27)$.

There are many other examples of early life programming of later life disorders (Table 1) (28-35), many of which we seldom consider in the context of "programming," that clearly require more research to determine their causal mechanisms and how to prevent and correct them. One of the most pressing of such problems is that although amino acid/protein deficiency is a principal cause of IUGR, efforts to date to correct growth restriction with protein supplements to pregnant women with IUGR placentas and fetuses actually can lead to worsening of IUGR, increased fetal and neonatal morbidity and mortality, and increased incidence of later life cardiovascular disease, obesity, diabetes, and activity of the hypothalamic-pituitary-adrenal axis (36-38). The most important cause of later life disorders, however, is preterm birth, which has increased over the past decade, from $10.6 \%$ of live births in the United States in 1990 to $12.5 \%$ in 2004, adding to its

Table 1. Less commonly considered examples of "programming"

\begin{tabular}{lc}
\hline & References \\
\hline $\begin{array}{l}\text { Iron deficiency in preterm infants leads to cognitive delays } \\
\text { Choline deficiency in fetuses predisposed to schizophrenia } \\
\text { enhances attention deficits, which worsens development } \\
\text { of schizophrenia }\end{array}$ & 29,30 \\
Omega-3 polyunsaturated essential fatty acids during fetal & 31 \\
development can modulate later pathogenesis and \\
degree of psychopathology
\end{tabular}

Table 2. Disease burden of preterm birth and low birth weight

Increased risk of dropping out of high school by one-third

Reduced annual earnings by almost $15 \%$ in adulthood

Increased health problems in $30 \mathrm{~s}$ and $40 \mathrm{~s}$

$30 \%$ less likely to be in "excellent or very good" health during childhood

Score significantly lower on reading and math achievement tests

Earlier death

Poor reproduction

Poor economic status of parents at the time of pregnancy leads to worse birth outcomes for their children, perpetuating a health, and socioeconomic crisis in future generations 
already devastating effect on the health and well being of these unfortunate children, as well as their families and society, who together bear a huge burden of poor health (Table 2) $(39,40)$.

\section{LESSONS FROM EARLY LIFE RESEARCH: ADAPTATIONS TO ADVERSE DEVELOPMENTAL INFLUENCES}

Studies such as those described above have provided important lessons about the nature and long-term outcome of adaptations to a variety of adverse conditions that can occur during fetal and neonatal development. First and foremost, normal development produces a balance that not only is successful, but that healthy babies, with their healthy mothers, have a much better opportunity to pass on their successful development to future generations. We also have learned that some adaptations during development can increase susceptibility to diseases in later life. This is not an insignificant problem. Some have estimated that as much as half of such later life disorders result from fetal growth restriction and fetal overgrowth. Importantly, most of these later life disorders could be prevented (4), if only we knew more about their causes.

\section{RESEARCH IN PEDIATRIC BIOLOGY AND MEDICINE IS UNDER FUNDED}

What is holding us back? The principal problem is that research in pediatric biology and medicine is under fundedmarkedly so. Whether because of competing costs of other national priorities, anti-intellectualism, or an overarching philosophy in this country that biomedical research will do better through the private sector, the U.S. has not increased discretionary money for research for over $35 \mathrm{y}$, since the early years of the space exploration and colonization program (41). This period spans both Republican and Democratic control in Congress and the Executive Branch of the federal government, so it cannot be blamed just on politics, although politics certainly have played a major role in the past few years.

This problem is underscored by the lack of increase in National Institutes of Health (NIH) funding in the past several years to even meet inflation levels. The 2009 request for NIH funding by the president of $\$ 29.2$ billion represents the sixth consecutive year that the president's proposed budget and congressional appropriations for NIH have failed to keep pace with biomedical inflation. If the president's 2009 budget for $\mathrm{NIH}$ is appropriated by Congress, it will represent a $14 \%$ decline in purchasing power over the president's terms in office $(42,43)$. A major result of this reduction in NIH funding will be to negate the advantage produced by the 1999-2004 budget doubling that was so important for getting NIH funding back to needed levels (Source: National Institutes of Health Budget Office: Congressional Appropriations, FY 1993-2006; 2007-2008 estimates; Pediatric Research Spending, FY 1993-2006; 2007-2008 estimates; Biomedical Research and Development Price Index, FY 2005-2008).

Cutting direct costs for grants also cuts indirect costs proportionally; even if the number of grants has not decreased at a given institution, the federal support to the institution for providing the infrastructure and maintenance for conducting research for those grants has decreased just as significantly. Many institutions are going further into debt as a result, because there are no other ready resources for such money (44). Thus, institutional as well as local and private sources of funds are becoming even more over burdened and less capable to compensate for the lack of NIH funds and come up with bridge and continuation support for established investigators or training and starter grants for young investigators.

The doubling of the NIH budget and several new funding mechanisms, such as the increased number and variety of mentored career development $(\mathrm{K})$ awards and the highly popular NIH loan repayment program, increased the number of scientists (especially younger individuals just embarking on their careers in academic medicine) and the number of research applications. These were both good and expected outcomes-just what the budget doubling was intended to accomplish. But increased applications for the new research support coupled with the more recent failure of the NIH budget to increase over the past several years have reduced the rate of successful funding of all NIH applications, from close to 55\% between 1998 and 2003 (the National Institutes of Health budget doubling period) to less than $20 \%$ in 2006 and 2007 , and the chance of an individual being funded by NIH on the first try, which has fallen from $21 \%$ for all investigators in 1998 to only $9 \%$ for first time applicants and 7\% for established investigators in 2006 (44,45).

More importantly for pediatric research is its even greater failure to keep up with NIH spending, before or after the doubling of the NIH budget. Pediatric research funding increased considerably less than $(82.4 \%)$ the overall NIH budget (98.3\%) during the budget doubling period, and actually fell from 13.1\% of the NIH budget in 1993 to $11.3 \%$ in 2005; this deficit has continued and worsened and will grow even greater if the president's 2009 budget is appropriated $(42,43)$. Furthermore, Congress has not yet appropriated new funds for the bi-partisan Pediatric Research Initiative that was central in the Children's Health Act of 2000, and NIH has not, as a result, shifted its overall research support in favor of funding for pediatric research $(42,43)$. It was not until specific language was added by Senator Edward Kennedy (D, Massachusetts) to the $\mathrm{NIH}$ reauthorization bill that pediatric research and training were specifically identified in the new NIH Clinical Translational Science Award program. Alternative funding organizations have tried but have not been fully able to keep up with the dramatically increased demand for grant support as pediatric scientists look elsewhere for funding. As a result, pediatric research is losing ground and children, not just pediatric scientists, will lose out on the critical need for new preventive measures and treatments of the many diseases that they suffer. Children and their research needs to understand, prevent, and treat diseases are being left behind, and even according to the current president, "left behind" is not where our children are supposed to be.

\section{POTENTIAL SOLUTIONS TO THE PROBLEM OF UNDER FUNDING OF PEDIATRIC RESEARCH}

What can we do about this fundamental problem? I believe that one very promising approach is to follow the lead set by 


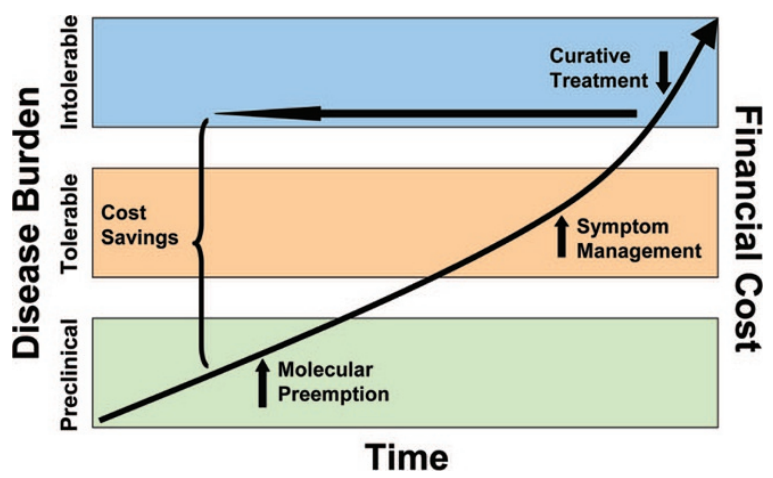

Figure 2. The "Future Paradigm: Preempt Disease." Adapted from Elias Zerhouni, MD, Director, National Institutes of Health, Fiscal Year 2008 Budget Request witness appearance before the House and Senate Subcommittees on Labor-HHS-Education Appropriations, March 6 and 19, 2007.

the Director of NIH, Dr. Elias Zerhouni, who pointed out (Fig. 2) that research that solves (prempts) problems at their beginning and prevents their future, cumulative, debilitating, and what should be intolerable effects on well being and financial costs is fundamentally what $\mathrm{NIH}$ and Congress should be spending their money on. Dr. Zerhouni called this "The Future Paradigm: Preempt Disease," moving from expensive and less effective symptom treatment and attempts at cures to prevention before diseases become clinically manifest.

More importantly for us to recognize as pediatricians, however, is the related concept that research into the causes, preventions, and treatments of diseases that begin very early in life will have a profound, life long impact on disease burden and financial costs. To use again the important example noted above, the financial burden of immediate and life long problems that stem from preterm birth are growing exponentially. In fact, the total NIH annual budget is worth the cost generated by only one year's worth of preterm births $(39,40)$. Recent initiatives by the March of Dimes, the U.S. Department of Health and Human Services, and the NIH (particularly NICHD) to develop new research and research support to help resolve causes of preterm birth are welcome responses to this major health problem.

I believe that we should take this "prevention-preemption" paradigm to heart and use it to support research into the causes, preventions, and treatments of diseases that begin very early in life. Learning more through fundamental research about the causes of intrauterine growth restriction, using the example from research in my laboratory, but also preterm birth, obesity, diabetes, inflammation, allergy, genetic diseases, and how essential nutrients and unnatural toxins affect brain development among other examples, will lead to the promise of improved health, not just in childhood, but over the lifespan - and on to future generations (Fig. 3). Such improvements in health will be equally or perhaps even more balanced by gains in economic advantage (46).

The principal point is that pediatric research has a much greater potential to preempt and prevent the life long burden and financial cost of diseases than investigations directed at problems that begin later in life. Such efforts should begin very early in life too, in conjunction with our obstetrical colleagues, recognizing that a healthy mother has a much

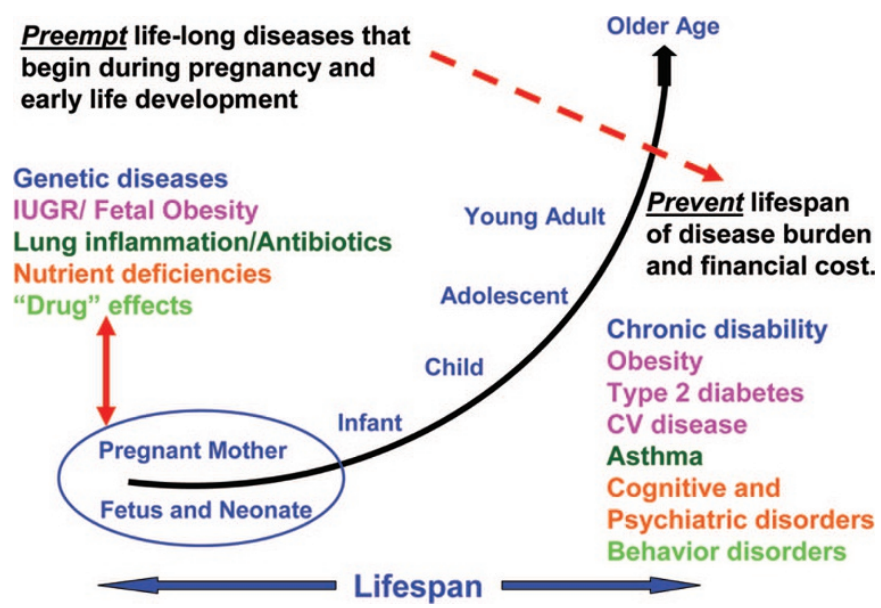

Figure 3. The unique advantage of research in early life. Research on disorders and interventions during gestation or in early life may lead to profound savings in disease burden and expenditures in later life.

better chance of producing a healthy infant, child, and adolescent, as well as a future healthy adult.

\section{SPECIFIC RECOMMENDATIONS TO INCREASE PEDIATRIC RESEARCH SUPPORT}

A reasonable first priority might be for the federal government to develop a strategy that would increase NIH funds to catch up and then keep up with inflation. Simply asking for more, however, will be the hardest sell of all and the least likely to work, given our country's current economic decline and expanding debt, competing research interests generated by our rapidly growing population of senior citizens, and the interests of many to develop broad, cross-disciplinary themes for research emphasis rather than focusing on age- or even disease-specific approaches. We also must accept the political reality that many in this country believe strongly in limiting government spending. They will not be easily persuaded to appropriate funds without solid evidence that they will get known value in return. Least of all will they look favorably on yet another entitlement indexed indefinitely to the inflation rate.

Better approaches would include requests for new support for already established programs that all can understand and support as uniquely and measurably beneficial for children, with evidence of value for their costs. A good start would be to add new dollars to the Pediatric Research Initiative of the Children's Health Act of 2000. This vital program has never received the funds necessary to successfully expand pediatric research to the level originally intended. The National Children's Study also needs new money to fully fund its original goals. The worst possible outcome of this major study would be, because of under funding, to end up with insufficient numbers of subjects and samples to provide accurate insight into the mechanisms that cause disease and how they progress over time. New funds, not just a portion of the funds already in existence, should be added for child and maternal clinical translational research to the NIH-National Center for Research Resources (NCRR) Clinical Translational Science Award program, providing increased opportunities for pediatric clinician-scientists to translate discoveries of disease mechanisms 
into therapies that then can be spread into the community. Similarly, specific funds also should be added for pediatric research components for all of the NIH roadmap initiatives.

I make no apology for encouraging support unique to pediatric research. Although it is nice to believe that over arching research themes naturally would include all age groups, this approach simply does not work as well for pediatrics when it has to compete with research focused on adult heart disease and cancer. In fact, age and disease specificity generally has gone the other direction. There is little evidence that this will change just by thinking it should. Women and children comprise $70 \%$ of the population but receive only $5 \%$ of NIH's research funding. Pediatric departments are among the most vulnerable in the face of the federal spending crunch, not just because they remain low on the list of the NIH's funding priorities, but because they often are overlooked or undervalued when they compete with proposals on issues like adult heart disease and cancer. In fact, in the mid-1990s, the U.S. Congress noted the "inadequate attention and resources devoted to pediatric research conducted and supported by National Institutes of Health" and specifically requested that the $\mathrm{NIH}$ develop performance indicators to measure its progress toward achieving a stronger pediatric research portfolio (U.S. House of Representatives Report No. 209, 104th Cong., 1st session, 1995, 80-81). Concerted effort will be required to see that pediatric research will get a larger fraction of whatever support NIH receives. The model noted earlier of developing a life span approach to research that starts on problems in early life but incorporates studies and outcomes throughout the life span should alleviate concerns regarding exclusivity of age group or disease specificity.

Pediatric research infrastructure also needs new money. A recent example of how this might be done is the National Pediatric Research Consortia Bill that was recently introduced into Congress. This bill intends to establish up to 20 pediatric research consortia, based on the national cancer center model, in which each consortium would consist of cooperative arrangements among institutions with core research capacities to support basic, clinical, behavioral, social, and translational research, as well as specific research training and advanced diagnostic and treatment methods in children. This program grew out of an entrepreneurial development by two members of the American Pediatric Society, David Williams and Thomas Boat, and has been supported by the APS Council since its inception. Hopefully, this Pediatric Research Consortia Bill will achieve the purpose of developing new money for proven approaches to basic and clinical-translational child health research.

I also strongly support increased funds for individual research grants, consistently the most effective strategy to make new discoveries that translate into improved health. Funding individual research projects also provides the most fertile ground for research training, by actually involving the trainees in doing the research alongside established and successful investigators. Such support simply provides opportunities-for the bright new scientists with the best new ideas and the careers of dedicated, hard work that have been the foundation of nearly all major discoveries in biology and medicine. New broadly-based research themes and cooperative, interactive, integrated, multidisciplinary approaches to research are increasingly promoted today and have their many benefits, particularly in developing research teams of investigators from many different disciplines to work together to solve increasingly complex problems and translate the results into community-based improvements in healthcare. But these new and valuable research enterprises all require that those involved bring something of value to the cooperative enterprise. This still will come primarily from individual scientists conducting their specific research projects and this will require much more support than now exists for pediatric scientists and their research projects.

\section{RECOMMENDATIONS FOR THE AMERICAN PEDIATRIC SOCIETY}

Based on these several observations, I would like to make several specific suggestions to the APS about what this society and its members could do to promote pediatric research support. It is an opportune time to do this, too, as the Pediatric Academic Societies (PAS) meeting, where we concentrate our time and efforts as a society, now is a relatively independent meeting, managed by its own organization, a truly wonderful accomplishment after a lot of hard work. The work of improving the PAS meeting certainly is not done, but its fabric is more of one piece now and much smoother, and it is appropriate, therefore, to look beyond the PAS meeting at how we as APS members could use our exceptional expertise to influence important issues in this country that would benefit children and their health.

First, APS Council could develop an agenda that focuses on important national issues, and personally, I believe that pediatric research should be our number one priority. I fully appreciate that most of us are very busy and we achieved the honor of membership in this society by participating fully in the fundamental activities that are required for membership. But no one better than us can provide the leadership to develop better research support for solving pediatric problems.

Second, such work is not just for the APS Council. Council and its leadership still need to focus on the PAS meeting to ensure that it prospers and grows robustly. APS membership needs to participate. I would like to recommend that APS Council, in collaboration with interested members, develop task forces focused on research development and research funding. And although I admit my bias that a focus on research should be first, as this initial effort achieves success, the APS membership and Council could then move on to new task forces focused on other essential needs for children, such as universal health insurance and access to healthcare, perhaps taking on such important programs one at a time so as not to dilute efforts in any one area and to maximize impact.

Third, the APS membership also needs more interaction with the Public Policy Council (PPC). The PPC is our representative organization to identify and support important public policy that affects children and their health, but it needs more voices behind it. Two or three members of the APS on the PPC of 1,676 total APS members simply is inadequate repre- 
sentation of the tremendous strengths that all of our members provide. Mike Genel, Karen Hendricks, and Jimmy Simon have faithfully reported to our Society about the activities of the PPC for many years, but reporting to us is not the bi-directional interaction that needs to take place if we are to participate effectively in the important activities of the PPC and the PPC in turn is to successfully represent and promote our interests.

Such increased participation and action by the members of the APS, The leaders in academic pediatrics, is essential. I'd like to think that we would have better success at developing new support for research that focuses on diseases that start early in life, but that's clearly a personal perspective, because I see that such research has the best chance to increase our capacity to reduce the burden of illness and financial costs that these diseases bring to children, during their childhood and over their entire lifespan. Believing in such a model, however, even with such clear potential, is not enough. We need to use our considerable expertise, get busy, and develop approaches that will achieve research support to make this model—or any other for pediatric research-successful.

Acknowledgments. The author thanks Duane Alexander, MD, for his insights into the operations of NICHD; Daniel Gitterman, $\mathrm{PhD}$, who helped provide much of the data regarding research funding through National Institutes of Health; Brenda Peat, Kathy Cannon, and Debbie Anagnostelis, whose work at the APS Central Office keeps the APS on such a successful track; and Judy Hay, whose support has been so absolutely fundamental.

\section{REFERENCES}

1. Battaglia FC 1978 Commonality and diversity in fetal development: bridging the interspecies gap. Pediatr Res 12:736-745

2. Perinatal Maturation. National Audiovisual Center (GSA), Springfield, VA 22161

3. Dabelea D, Hanson RL, Lindsay RS, Pettitt DJ, Imperatore G, Gabir MM, Roumain J, Bennett PH, Knowler WC 2000 Intrauterine exposure to diabetes conveys risks for type 2 diabetes and obesity: a study of discordant sibships. Diabetes 49:2208-2211

4. Barker DJ 1995 Fetal origins of coronary heart disease. BMJ 311:171-174

5. Ozanne SE, Fernandez-Twinn D, Hales CN 2004 Fetal growth and adult diseases. Semin Perinatol 28:81-87

6. Godfrey KM, Lillycrop KA, Burdge GC, Gluckman PD, Hanson MA 2007 Epigenetic mechanisms and the mismatch concept of the developmental origins of health and disease. Pediatr Res 61:5R-10R

7. McMillen IC, Robinson JS 2005 Developmental origins of the metabolic syndrome: prediction, plasticity, and programming. Physiol Rev 85:571-633

8. Barker DJ 2004 The developmental origins of adult disease. J Am Coll Nutr 23:588S-595S

9. Hanson MA, Gluckman PD 2008 Developmental origins of health and disease: new insights. Basic Clin Pharmacol Toxicol 102:90-93

10. Lucas A 1991 Programming by early nutrition in man. Ciba Found Symp 156:38-50

11. DiGiacomo JE, Hay WW Jr 1990 Fetal glucose metabolism and oxygen consumption during sustained maternal and fetal hypoglycemia. Metabolism 39:193-202

12. Wallace JM, Milne JS, Aitken RP, Hay WW Jr 2007 Sensitivity to metabolic signals in late gestation growth restricted fetuses from rapidly growing adolescent sheep. Am J Physiol Endocrinol Metab 293:E1233-E1241

13. Limesand SW, Rozance PJ, Smith D, Hay WW Jr 2007 Increased insulin sensitivity and maintenance of glucose utilization rates in fetal sheep with placental insufficiency and intrauterine growth restriction. Am J Physiol Endocrinol Metab 293:E1716-E1725

14. Das UG, Schroeder RE, Hay WW Jr, Devaskar SU 1999 Time-dependent and tissue-specific effects of circulating glucose on fetal ovine glucose transporters. Am J Physiol 276:R809-R817

15. Hales CN, Barker DJ 2001 The thrifty phenotype hypothesis. Br Med Bull 60:5-20
16. Ross JC, Fennessey PV, Wilkening RB, Battaglia FC, Meschia G 1996 Placental transport and fetal utilization of leucine in a model of fetal growth retardation. Am J Physiol 270:E491-E503

17. Carver TD, Quick AA, Teng CC, Pike AW, Fennessey PV, Hay WW Jr 1997 Leucine metabolism in chronically hypoglycemic, hypoinsulinemic growth restricted fetal sheep. Am J Physiol 272:E107-E117

18. Limesand SW, Jensen J, Hutton JC, Hay WW Jr 2005 Diminished beta-cell replication contributes to reduced beta-cell mass in fetal sheep with intrauterine growth restriction. Am J Physiol Regul Integr Comp Physiol 288:R1297-R1305

19. Limesand SW, Rozance PJ, Zerbe GO, Hutton JC, Hay WW Jr 2006 Attenuated insulin release and storage in fetal sheep pancreatic islets with intrauterine growth restriction. Endocrinology 147:1488-1497

20. Ehrenkranz RA, Younes N, Lemons JA, Fanaroff AA, Donovan EF, Wright LL, Katsikiotis V, Tyson JE, Oh W, Shankaran S, Bauer CR, Korones SB, Stoll BJ, Stevenson DK, Papile LA 1999 Longitudinal growth of hospitalized very low birth weight infants. Pediatrics 104:280-289

21. Meier PR, Peterson RG, Bonds DR, Meschia G, Battaglia FC 1981 Rates of protein synthesis and turnover in fetal life. Am J Physiol 240:E320-E324

22. Ziegler EE, O'Donnell AM, Nelson SE, Fomon SJ 1976 Body composition of the reference fetus. Growth 40:329-341

23. Thureen PJ, Melara D, Fennessey PV, Hay WW Jr 2003 Effect of low versus high intravenous amino acid intake on very low birth weight infants in the early neonatal period. Pediatr Res 53:24-32

24. Denne SC, Poindexter BB 2007 Evidence supporting early nutritional support with parenteral amino acid infusion. Semin Perinatol 31:56-60

25. Lucas A, Morley R, Cole TJ, Morley R, Fewtrell MS, Abbott RA, Stephenson T, MacFadyen U, Lucas A 1998 Randomized trial of early diet in preterm babies and later intelligence quotient. BMJ 317:1481-1487

26. Isaacs EB, Gadian DG, Sabatini S, Chong WK, Quinn BT, Fischl BR, Lucas A 2008 The effect of early human diet on caudate volumes and IQ. Pediatr Res 63:308-314

27. Hüppi PS 2008 Nutrition for the brain. Pediatr Res 63:229-231

28. Lozoff B, Georgieff MK 2006 Iron deficiency and brain development. Semin Pediatr Neurol 13:158-165

29. Freedman R, Ross RG, Leonard S, Worsley M, Adams C, Waldo M, Tregellas J, Martin L, Olincy A, Tanabe J, Kisley M, Hunter S, Stevens K 2005 Early biomarker of psychosis. Dialogues Clin Neurosci 7:17-29

30. Stevens KE, Adams CE, Yonchek J, Hickel C, Danielson J, Kisley MA 2008 Permanent improvement in deficient sensory inhibition in DBA/2 mice with increased perinatal choline. Psychopharmacology (Berl) 198:413-420

31. McNamara RK, Carlson SE 2006 Role of omega-3 fatty acids in brain development and function: potential implications for the pathogenesis and prevention of psychopathology. Prostaglandins Leukot Essent Fatty Acids 75:329-349

32. Abate P, Pueta M, Spear NE, Molina JC 2008 Fetal learning about ethanol and later ethanol responsiveness: evidence against "safe" amounts of prenatal exposure. Exp Biol Med (Maywood) 233:139-154

33. Rivkin MJ, Davis PE, Lemaster JL, Cabral HJ, Warfield SK, Mulkern RV, Robson CD, Rose-Jacobs R, Frank DA 2008 Volumetric MRI study of brain in children with intrauterine exposure to cocaine, alcohol, tobacco, and marijuana. Pediatrics 121:741-750

34. Kotch JB, Lewis T, Hussey JM, English D, Thompson R, Litrownik AJ, Runyan DK, Bangdiwala SI, Margolis B, Dubowitz H 2008 Importance of early neglect for childhood aggression. Pediatrics 121:725-731

35. Alm B, Erdes L, Möllborg P, Pettersson R, Norvenius SG, Åberg N, Wennergren G 2008 Neonatal antibiotic treatment is a risk factor for early wheezing. Pediatrics 121:697-702

36. Herrick K, Phillips DI, Haselden S, Shiell AW, Campbell-Brown M, Godfrey KM 2003 Maternal consumption of a high-meat, low-carbohydrate diet in late pregnancy: relation to adult cortisol concentrations in the offspring. J Clin Endocrinol Metab $88: 3554-3560$

37. Say L, Gülmezoglu AM, Hofmeyr GJ 2003 Maternal nutrient supplementation for suspected impaired fetal growth. Cochrane Database Syst Rev 2003:CD000148

38. Kramer MS, Kakuma R 2003 Energy and protein intake in pregnancy. Cochrane Database Syst Rev 2003:CD000032

39. Behrman RE, Stith Butler A 2006 Preterm birth: causes, consequences, and prevention. National Academies Press, Washington, DC (Available at: http://nap.edu)

40. Johnson RC, Schoeni RF 2007 The influence of early-life events on human capital, health status, and labor market outcomes over the life course. Institute for Research on Labor and Employment. Institute for Research on Labor and Employment Working Paper Series. Paper iirwps-140-07. (Available at: http://repositories.cdlib. org/iir/iirwps/iirwps-140-07)

41. Mervis J 2007 Budget policy. U.S. science adviser tells researchers to look elsewhere. Science 316:817-818

42. Gitterman DP, Greenwood RS, Kocis KC, Mayes BR, McKethan AN 2004 Did a rising tide lift all boats? The NIH budget and pediatric research portfolio. Health Aff (Millwood) 23:113-124

43. Gitterman D, Hay WW Jr 2008 "That Sinking Feeling, Again . .." The State of Pediatric Research Spending at NIH, FY 1993-2010. Pediatr Res doi:10.1203/PDR Ob013e31818912fd

44. Heinig SJ, Krakower JY, Dickler HB, Korn D 2007 Sustaining the engine of U.S biomedical discovery. N Engl J Med 357:1042-1047

45. Couzin J, Miller G 2007 NIH budget. Boom and bust. Science 316:356-361

46. Alderman H, Behrman JR, Hoddinott J 2007 Economic and nutritional analyses offer substantial synergies for understanding human nutrition. J Nutr 137:537-544 